\title{
Vocal Cord Nodule
}

National Cancer Institute

\section{Source}

National Cancer Institute. Vocal Cord Nodule. NCI Thesaurus. Code C3370.

A non-neoplastic growth in the vocal cord. It is characterized by tissue swelling in both vocal cords in a symmetrical manner. It is caused by vocal abuse behavior. Hoarseness is the presenting symptom. 